\title{
Toward Better Goal Clarity in Instruction: How Focus On Content, Social Exchange and Active Learning Supports Teachers in Improving Dialogic Teaching Practices
}

\author{
Martina Alles ${ }^{1}$, Tina Seidel ${ }^{1} \&$ Alexander Gröschner ${ }^{2}$ \\ ${ }^{1}$ TUM School of Education, Technical University Munich (TUM), Munich, Germany \\ ${ }^{2}$ Department of Educational Science, Friedrich-Schiller-Universtity, Jena, Germany \\ Correspondence: Martina Alles, TUM School of Education, Technical Universtity Munich (TUM), Arcisstraße 21, \\ 80333 Munich, Germany. Tel: 49-89-2892-4379. E-mail: martina.alles@tum.de
}

Received: August 11, 2017

doi:10.5539/ies.v11n1p11
Accepted: October 16, 2017 Online Published: December 22, 2017

URL: https://doi.org/10.5539/ies.v11n1p11

\begin{abstract}
Goal clarity is an essential element of classroom dialogue and a component of effective instruction. Until now, teachers have been struggling to implement goal clarity in the classroom dialogue. In the present study, we investigated the classroom practice of teachers in a video-based intervention called the Dialogic Video Cycle (DVC) and compared it to the classroom practice of teachers in a traditional control group. We conducted video analysis $(N=20$ lessons) of teaching practices at the beginning (pre-test) and at the end of the school year (post-test). Furthermore, we performed video analysis of intervention group teacher discussions during DVC meetings ( $N=6$ meetings). Comparative analysis between groups revealed changes in teaching practices towards better goal clarity for DVC teachers in comparison to the traditional control group. In-depth analysis of teacher discussions during DVC meetings showed that teachers continuously focused on goal clarity as the content of teacher professional development (TPD). They shared learning experiences and were actively involved in TPD learning activities. The study illustrates how components of effective TPD programs (content focus, social and active learning) translated into redefining and changing the teaching practice.
\end{abstract}

Keywords: classroom dialogue, goal clarity, teacher professional development, teacher learning, video analysis

\section{Introduction}

\subsection{Introduction of the Problem}

Classroom dialogue is the predominant mode of teaching in many classrooms all over the world (Mercer \& Dawes, 2014). It is typically dominated by a rigid interaction pattern (Mehan, 1979; Resnick, Asterhan, \& Clarke, 2015) and does not motivate students sufficiently to participate in discourse (Seidel \& Prenzel, 2006). In this context, teachers fail to explicate learning goals and to verbally structure the course of the lessons well (Hugener et al., 2009; Seidel, Rimmele, \& Prenzel, 2005).

In order to support teachers in changing their teaching practice, teacher professional development (TPD) programs have been developed (Resnick et al., 2015). In general, TPD aims to refresh the competencies of teachers' initial education and to expand teachers' professional knowledge and skills for further tasks and functions (Timperley, Wilson, Barrar, \& Fung, 2007; Vigerske, 2017).

In this study, we present findings of the Dialogic Video Cycle (DVC). The DVC is a video-based TPD program focusing on productive classroom dialogue (Gröschner, Seidel, Kiemer, \& Pehmer, 2015). Previous research shows that video-based TPD elements strengthen teachers' capacities for making concrete changes (Ball \& Cohen; Borko, Jacobs, Eiteljorg, \& Pittman, 2008; Grossman, Compton, Igra, Ronfeldt, \& Shahan, Emily, Williamson, Peter W., 2009). We designed a more traditional TPD program called the Advanced Traditional Program (ATP) for the control group. In the ATP, teachers took part in one-shot workshops on the same topic offered by the Teachers' Professional Development Academy in Dillingen, Germany, but they did not work with video recordings of their own teaching. More information about the design of both programs is provided in section 2.1.

The aim of the study was to add value to the question of how teacher learning in TPD can be related to changes 
in teaching practice. Until now, a number of studies have examined the effects of TPD by investigating changes in teachers' knowledge and practices as well as student achievement (Reznitskaya \& Wilkinson, 2015; Sedova, Sedlacek, \& Svaricek, 2016). Hattie (2009), for example, summarized findings from more than 50000 studies and reported a mean effect size of $d=0.62$ for the effect TPD has on student achievement. Recent efforts also examined indicators of teacher learning during TPD (Borko et al., 2008; van Es, 2011). For instance, Borko and colleagues (2008) presented findings from teachers' exchange during their 2-year mathematics TPD program. Their findings indicated that teachers' conversations about video developed over time. It was shown that the conversation seemed to support teacher learning and motivated them to improve their teaching skills. However, there have only been a few studies connecting teacher learning in TPD with changes in teaching practice.

Our study contributes to the state of TPD research by first examining DVC teachers' classroom practice before and after the intervention and systematically comparing it to the control group (Research Question 1). In a second step, DVC teachers' discussions were analyzed to get deeper insights into teacher learning during the TPD program (Research Question 2). We used qualitative excerpts of teacher discussions to illustrate our findings.

In the following, we first describe the theoretical and empirical state of research (Section 1.2.). Section 1.3 then presents the research questions. Section 2 provides an overview of the methodological approach and Section 3 presents the main findings. Section 4 concludes with a discussion of the main findings as well as the further implications for TPD practice and research.

\subsection{Theoretical Background}

This section is divided into two subsections. Subsection 1.2.1 introduces the concept of classroom dialogue and especially focuses on goal clarity as an element of productive classroom dialogue. Subsection 1.2.2 considers helpful elements for teacher learning within the context of TPD programs. Three elements will be highlighted: Content focus, active learning in a social community of learners, and video as a supportive tool for learning in TPD.

\subsubsection{Goal Clarity as an Element of Productive Classroom Dialogue}

Classroom dialogue can provide students with rich opportunities to engage in discourse, to think together and to elaborate on their own ideas (Alexander, 2008; Osborne, Simon, Christodoulou, Howell-Richardson, \& Richardson, 2013). However, especially in math and science lessons, classroom dialogue typically follows tight communication structures, so-called initiation-response-evaluation (IRE) patterns (Mehan, 1979; Mercer \& Dawes, 2014). According to this pattern, teachers typically initiate (I) classroom dialogue by asking narrow questions. The students then provide brief responses (R) and teachers evaluate (E) students' responses quickly. These tight interaction patterns fail to activate and challenge students sufficiently (Howe \& Abedin, 2013; Kovalainen \& Kumpulainen, 2005). Therefore, efforts have been made to train teachers to improve their dialogic strategies. For instance, in the TPD program "Accountable Talk" (Michaels, O'Connor, \& Resnick, 2008), teachers learn concrete "talk moves" for improving their classroom dialogue. "Talk moves" refer to the conversational practices teachers can use to activate students and to scaffold their responses, such as asking a student to restate a previous response in his/her own words.

Within the context of dialogic teaching, goal clarity is often not implemented clearly (Borich, 2014; Seidel \& Prenzel, 2006). Teachers struggle to explicate teaching and learning goals, as well as to make planned teaching and learning processes transparent. However, the clear communication of lesson goals and the presentation of the content structure have positive effects on students' learning processes and motivation (Hugener et al., 2009; Rakoczy et al., 2007; Seidel, Rimmele et al., 2005). Seidel and Shavelson (2007), for instance, conducted a meta-analysis with 112 studies on various teaching strategies. They found that goal setting and orientation had positive effects on students' learning processes, motivation, and cognitive achievement.

The TPD program presented in this study is the one-year video-based Dialogic Video Cycle (DVC). It aims to improve classroom dialogue through the activation of students and the scaffolding of students' learning processes (Walshaw \& Anthony, 2008). The first activity comprises the clarification of rules and responsibilities as a basis for a productive classroom dialogue. It aims to activate students to participate in teacher-student interactions. The second activity comprises strategies to scaffold students' ideas. In this study, we focused on goal clarity as an essential instructional strategy for the activation of students (first activity).

But how can teachers be supported in changing their actual teaching practices? How can teachers learn to activate students in classroom dialogue and clarify the learning goals? The following subsection focuses on teacher learning in TPD. An overview of essential elements for teacher learning is given. 


\subsubsection{Teacher Learning within the Context of Teacher Professional Development}

From previous research (Scheerens, 2010; Stoll, Bolam, McMahon, Wallace, \& Thomas, 2006) we know that teacher learning communities can support teachers' professional development. A learning community is defined as a group of teachers coming together for a sustained period of time to collaborate on and discuss their teaching with regard to shared content and goals (DuFour \& Eaker, 1998; van Es, 2012).

The most important element in supporting teacher learning in learning communities is content focus (Desimone, 2009). Focusing on specific content means that the TPD program attends to a specific subject or pedagogical content that is related to the teaching practice, such as classroom dialogue (Desimone, 2009; Wilson, 2013). To foster teachers' content focus, it is helpful to have 20 hours of contact time or more, spread out over a longer time span (Lauer et al., 2014). Teachers need some time to get to know each other and to evolve into a learning community with shared goals and interests (Dobie \& Anderson, 2015; van Es, 2012). To situate the content into practice, artifacts of learning, such as lesson plans, teaching materials, students' work or videos of lessons, are useful tools to support teacher learning (Ball \& Cohen, 1999; Lampert, 2009).

Beside content focus, active learning in professional learning communities supports teacher professional development (Scheerens, 2010; Vangrieken, Meredith, Packer, \& Kyndt, 2017). Active learning takes place when teachers take part in productive discussions about their teaching (Borko et al., 2008; Dobie \& Anderson, 2015). According to Borko and colleagues (2008, p. 421), productive discussions "should promote a critical examination of teaching, they should enable teachers to collectively explore ways of improving their teaching and support one another as they work to transform their practice". Van Es' (2012) findings, for instance, show how a group of teachers starting at the beginning level of a teacher learning community evolve into a highly engaged community with a shared commitment between teachers and facilitators to support each other's learning. To foster teachers' active learning, the TPD facilitator's task is to encourage all teachers to take part in the exchange (Arya, Christ, \& Chiu, 2014; Molle, 2013; van Es, Tunney, Seago, \& Goldsmith, 2015).

Taking the large body of research during the last years into consideration, video can be understood as a third supportive aspect for learning in TPD (Gaudin \& Chaliès, 2015). Carefully selected video teaching excerpts provided opportunities to relate TPD contents to the teachers' practices and to enhance TPD content demonstratively (Ball \& Cohen; Coles, 2013; Jacobs, Borko, \& Koellner, 2009). Video excerpts of their own teaching enabled the teachers to observe their own teaching from a new (outside) perspective and to identify teaching aspects they had not detected during the lesson (Krammer et al., 2006; Marsh \& Mitchell, 2014). Video excerpts of other teachers, on the other hand, allowed them to see instructional strategies other teachers use (Marsh \& Mitchell, 2014; Zhang, Koheler, \& Lundeberg, 2015). Teachers were more engaged in the content when watching videos of their own teaching than when watching other teachers teach (Seidel, Stürmer, Blomberg, Kobarg, \& Schwindt, 2011). Teachers were more encouraged to analyze problematic events and implement new content into their teaching practice when watching video recordings of others (Kleinknecht \& Schneider, 2013; Moreno \& Valdez, 2007).

The TPD programs of the present study were developed based on theoretical assumptions (Borko, 2004; Desimone, 2009; Scheerens, 2010) and empirical findings (Borko et al., 2008; Seidel et al., 2011; van Es, 2012). The video-based Dialogic Video Cycle (DVC) served as an intervention group and the Advanced Tradtional Program (ATP) as control group. Further details about the design of the two programs are outlined in Chapter 2.1 .

\subsection{Research Questions and Conjectures}

Two main research questions were addressed. The first question focused on teachers' change in practice. The second referred to teachers' learning during the DVC program.

1) To what extent do DVC teachers change their teaching practices toward better goal clarity in classroom dialogue in comparison to ATP teachers?

2) How can these practice changes be linked to teacher discussions during DVC meetings?

2.1) To what extent do teachers' exchange focus on the content of goal clarity in classroom dialogue?

2.2) To what extent do the teachers actively participate verbally in the discussions?

First, we expected that the DVC would provide more situated learning opportunities for teachers to change teaching practices than the ATP. Therefore, positive changes from pre to post-test for better goal clarity were expected for DVC teachers in comparison to ATP teachers (conjecture 1).

Second, we assumed that the video-based approach of the DVC supported teachers in continuously focusing their discussions on the content (conjecture 2a). Furthermore, we expected that teachers in the DVC learning 
community and the teacher on-screen (whose video was being discussed) would be continuously active verbally in the social exchange of experiences (conjecture 2b).

\section{Method}

\subsection{Implementation of the Teacher Professional Development Programs}

As mentioned before, the two TPD programs (Dialogic Video Cycle (DVC) and Advanced Traditional Program (ATP)) were developed. An implementation study showed that both programs generally targeted effective components, such as pedagogical content focus (on classroom dialogue), comparable durations (22 hours) and coherence (Gröschner et al., 2015). The components of collective participation and active learning were fully observed in the DVC and targeted in the ATP at an intermediate level. In the following, the two programs are described in detail and Figure 1 provides a visual comparison.

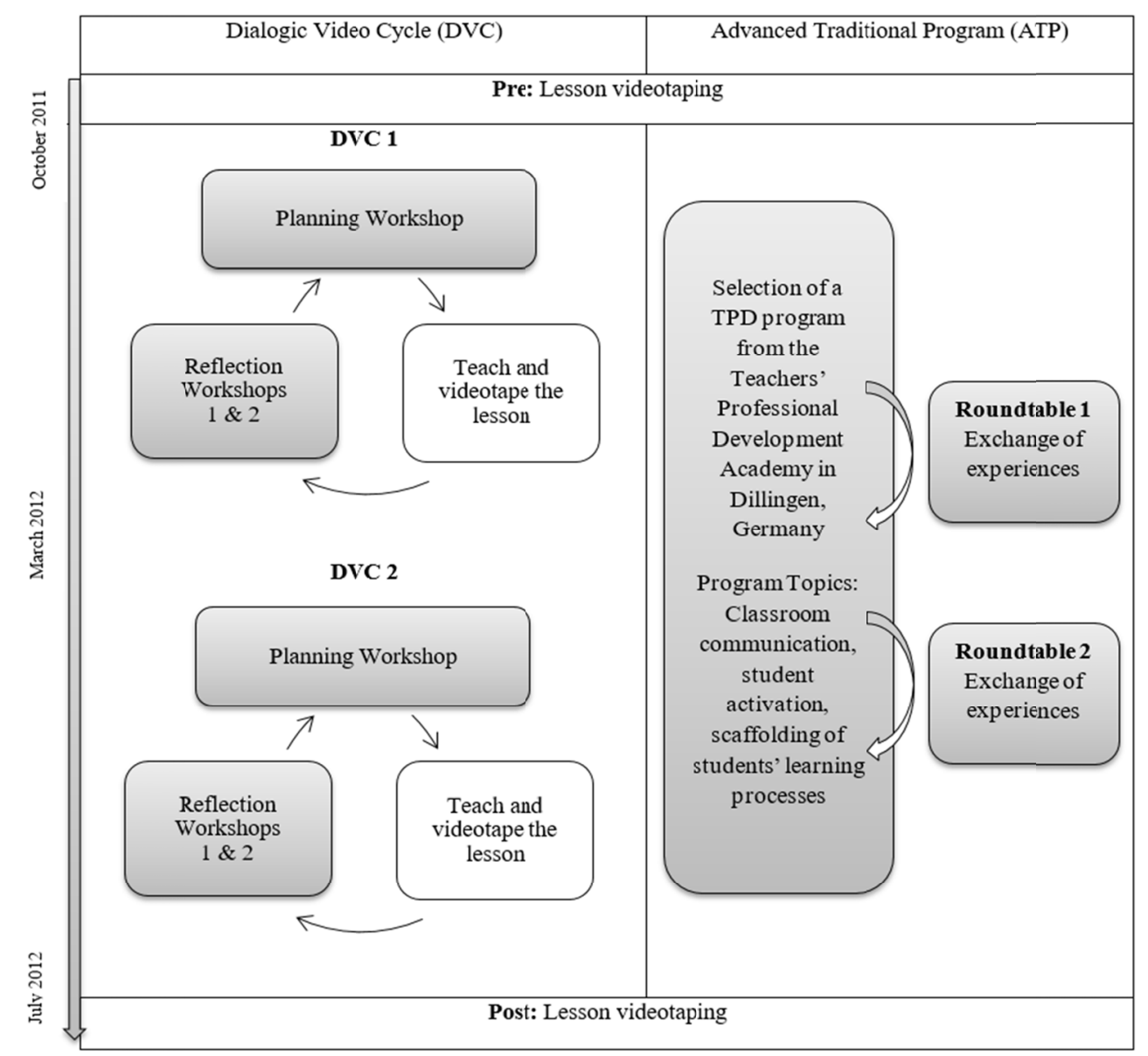

Figure 1. Overview of the Teacher Professional Development programs and measuring points

\subsubsection{Dialogic Video Cycle (DVC)}

The DVC was applied in a systematic study in the academic year 2011-2012. The main goal was to empower teachers to change their teaching practice in a way that would activate their students to participate in classroom dialogue and support their learning processes (Walshaw \& Anthony, 2008).

The DVC was composed of two subsequent cycles (Figure 1), one for the first term of the school year (DVC 1) and one for the second term (DVC 2). Each cycle consisted of three interconnected workshops (about 120 minutes each) and a videotaped lesson of every teacher (about 45 minutes).

In each DVC planning workshop, the facilitator provided a knowledge base on classroom dialogue and introduced conversation rules for appreciated discussions. Then, the facilitator invited the teachers to implement at least three activities for productive classroom dialogue in an existing lesson plan. Following this, the 
facilitator supported teachers' discussions about the adoption of lesson plans (Gröschner, Seidel, Pehmer, \& Kiemer, 2014).

After the planning workshop, the adopted lesson was taught and videotaped by the research team. Two to three-minute video excerpts of each teacher were chosen for the joint discussion in the following reflection workshops.

In the two reflection workshops of each DV cycle, the teachers watched the video excerpts and discussed their experiences teaching the lessons. The discussion was led by the facilitator who, for instance, repeated the knowledge base of a productive classroom dialogue and provided guiding questions like "How did Laura (teacher in the DVC) ensure that all students understood the goal of the lesson?"

\subsubsection{Advanced Traditional Program (ATP)}

The ATP was conducted during the same school year. The ATP was developed similar to a traditional German TPD program in which teachers chose one-shot workshops on specific teaching and learning topics (Richter, Kunter, Klusmann, Lüdtke, \& Baumert, 2011). In this study, the research team selected a number of workshops with comparable durations on the topic of productive classroom dialogue and effective components of teaching and learning (such as goal clarity), which were offered by the Teachers' Professional Development Academy in Dillingen, Germany. The teachers were free to choose a set of these pre-selected programs. In order to foster the community of teachers as learners, two additional roundtables were offered by the facilitator. These roundtables are not typical for German TPD, which is why the program was called an Advanced Traditional Program (ATP). In contrast to the DVC, the teachers in the ATP program did not explicitly adopt existing lesson plans and they did not explicitly reflect on concrete examples of teaching practices as shown in video excerpts of their own teaching.

\subsection{Participant Characteristics}

Ten math and science teachers from higher and lower secondary schools in the Munich metropolitan area in Germany participated voluntarily in the TPD programs (Gröschner et al., 2015). TPD in Germany is normally based on the voluntary participation of teachers, so the two programs met the organizational standards and usual routines.

Table 1. Teacher sample

\begin{tabular}{ccccccc}
\hline Teacher pseudonym & Intervention & Age & Gender & Teaching experience & Subject & Secondary level \\
\hline Sarah & DVC & 39 & F & 10 & Math & High \\
Marc & DVC & 45 & M & 4 & Math & Low \\
Laura & DVC & 33 & F & 2 & Physics & Low \\
Caroline & DVC & 44 & F & 5 & Physics & High \\
Lucy & DVC & 33 & F & 2 & Math & High \\
Thomas & DVC & 43 & M & 5 & Math & Low \\
Peter & ATP & 43 & M & 10 & Physics & High \\
Susan & ATP & 30 & F & 4 & Math & High \\
Helena & ATP & 33 & F & 7 & Biology & High \\
Karin & ATP & 40 & F & 8 & Physics & High \\
\hline
\end{tabular}

After participating in a pre-meeting about the programs, the teachers chose one of the two programs (DVC or ATP). Teachers were not told which program would function as the intervention group versus the control group. Six teachers chose to participate in the DVC and four in the ATP. The teachers in the two programs did not differ in their motivation to learn about productive classroom dialogue (four-point Likert scale) $(U=7.00, z=-1.14, p$ $=.25)$ during their participation in the DVC $\left(M=3.51, S D=.47 ; M_{\text {Rank }}=4.67\right)$ or the ATP $(M=3.81, S D=.38$; $\left.M_{\text {Rank }}=6.75\right)$ (Gröschner et al., 2014). In addition, teachers' characteristics in the DVC and ATP showed no significant differences in age, teaching experience, gender or subject (math and science) between the two programs (Pehmer, Gröschner, \& Seidel, 2015).

\subsection{Video Coding}

Each teacher's classroom practice was video recorded at the beginning and the end of the 2011/12 school year (video recording of teaching practice). Furthermore, all DVC workshops were additionally video recorded (video recording of teacher discussion). 


\subsubsection{Video Coding of Teaching Practice (Research Question 1)}

There were 20 video recordings of classroom dialogue teaching practice ( $n=10$ for pre-test, $n=10$ for post-test). The recordings were coded by two independent raters using the software Videograph (Rimmele, 2002). In order to examine research question 1, the lesson served as a unit of analysis. A rating scheme based on four items (see Table 2$)$ to be rated on a four-point Likert scale was used $(0=$ not true, $1=$ partly not true, $2=$ partly true, $3=$ true) (Seidel, Prenzel, \& Kobarg, 2005). Reliability, by means of calculating independent inter-rater correlations, was satisfactory (ICC: $\mathrm{M}=.58$ ).

To give an example, the raters watched Sarah's lesson (teacher participating in the DVC) for the pre-test. Afterward, each rater individually rated the lesson based on the four items (see Table 2). The raters had detailed coding rules for every item. When necessary, consent validation followed the independent coding procedure.

\subsubsection{Video Coding of Teacher Discussions (Research Question 2)}

In addition to the recordings of the teaching practice, there were six ( $n=3$ for DVC $1, n=3$ for DVC 2) video recordings of teacher discussions during the DVC workshops. These were coded based on a two-minute unit of analysis and three analysis categories $(0=$ miss, $1=$ hit, $2=$ not applicable $)$. The coding followed procedures applied in previous research (Borko et al., 2008; Seidel, Prenzel et al., 2005). The total number of video coded units of analysis was $344(M=57.3 ; S D=19.53)$. Although every workshop was about two hours long, the number of units of analysis differed between the workshops (Minimum $=35$, Maximum $=83$ ). There were more units of analysis in the DVC planning workshops than in the reflection workshops. In the planning workshops, several small group discussions took place simultaneously. For the video coding, we added the units of analysis of the simultaneous discussions being run and therefore got a higher number of two-minute units of analysis in the planning workshops. In addition, we did not consider units of the reflection workshops in which teachers watched the video excerpts and no discussion took place.

Each unit of analysis was coded with regard to the focus on goal clarity in classroom dialogue. Furthermore, we analyzed who participated in the discussion: a) facilitator, b) teacher on-screen, c) teachers in the learning community. Reliability, by means of calculating independent inter-rater correlations, ranged from satisfactory to excellent (ICCs: 0.65 to 1.00).

To give an example, the raters observed teachers' discussion in the planning workshop of DVC 1 . They stopped the recording every two minutes and rated each segment based on all items (see Table 2). In addition, they rated who participated in the discussion during the two minutes.

Table 2. Categories for video coding

\begin{tabular}{|c|c|c|c|}
\hline Coding category & Video material & Item & $\begin{array}{l}\text { Coding role: } \\
\text { Is coded if... }\end{array}$ \\
\hline \multirow{4}{*}{$\begin{array}{l}\text { Change in teaching practice } \\
\text { (Research Question 1) }\end{array}$} & \multirow{4}{*}{$\begin{array}{l}\text { Teaching } \\
\text { practice videos }\end{array}$} & Goal formulation & $\begin{array}{l}\text {...the teacher formulates the main goal/central question } \\
\text { of the lesson. }\end{array}$ \\
\hline & & General concept & $\begin{array}{l}\text {...the lesson is structured according to the teacher's } \\
\text { general concept. }\end{array}$ \\
\hline & & Lesson structure & $\begin{array}{l}\text {...the teacher chooses an appropriate student working } \\
\text { phase and integrates it into the structure of the lesson } \\
\text { meaningfully. }\end{array}$ \\
\hline & & Specific goals & $\begin{array}{l}\text {...the goals are formulated specifically and not } \\
\text { generally. }\end{array}$ \\
\hline $\begin{array}{l}\text { Change in the DVC's discussions } \\
\text { about goal clarity (Research }\end{array}$ & $\begin{array}{l}\text { DVC } \\
\text { workshop } \\
\text { videos }\end{array}$ & $\begin{array}{l}\text { Clarification of lesson } \\
\text { course and student tasks }\end{array}$ & $\begin{array}{l}\text {...clarification of lesson course and student tasks is } \\
\text { discussed. }\end{array}$ \\
\hline Question 2) & & $\begin{array}{l}\text { Clarification of learning } \\
\text { goals }\end{array}$ & $\begin{array}{l}\text {...clarification of goals as a possibility to activate } \\
\text { students is discussed. }\end{array}$ \\
\hline
\end{tabular}

\subsection{Data Analysis}

\subsubsection{Data Analysis of Change in Teaching Practice (Research Question 1)}

Due to the sample size $(N=10)$, non-parametric variance analyses for longitudinal comparisons of the two groups (DVC and ATP) were applied using the software R (Stowell, 2014). Thus, we compared the relative 
effects of DVC and ATP. Additionally, since conventional analyses typically refer to parametric analyses, the findings are reported by means of a Wilcoxon signed-rank test. These analyses were applied separately to show changes for each TPD program from pre- to post-test.

\subsubsection{Data Analysis of Teacher Discussions (Research Question 2)}

Due to the variation in the number of two-minute units of analysis for each DVC workshop, we report results for each conjecture based on the absolute and relative frequencies of the rated DVC items. Furthermore, we present a mean value for both reflection workshops of each cycle, as the main interest was in the nature and change of the DVC discussions over time (from DVC 1 to DVC 2). In addition, we differentiate between the proportion of verbal activity in the discussions among facilitators, on-screen teachers and teachers in the learning community. Due to the fact that video excerpts of one's own teaching were only used in the reflection workshops, we only report the on-screen teachers' verbal activity for these workshops. Finally, discussions from the DVC workshops were transcribed and presented as qualitative excerpts.

\section{Results}

The following results are presented according to the research questions and conjectures. The first section (3.1) starts by demonstrating the findings for the change in teaching practice. The second section (3.2) illustrates the findings for teacher learning during the DVC program.

\subsection{Change in Teaching Practice (Research Question 1)}

Based on the non-parametric variance analysis for longitudinal comparisons of the two TPD programs, the investigation of teachers' practice changes regarding goal clarity showed a significant interaction effect $(F=4.84$, $d f=1, p=0.03)($ see Table 3$)$.

Table 3. Changes in teaching practice in the DVC and ATP

\begin{tabular}{cccccccccc}
\hline \multicolumn{3}{c}{ Pre } & \multicolumn{7}{c}{ Post } \\
\hline \multirow{2}{*}{ DVC } & $M(S D)$ & Mean rank & RTE & $M(S D)$ & Mean rank & RTE & $F$ & $d f$ & $p$ \\
\cline { 2 - 10 } ATP & $1.5(.8)$ & 7.8 & .4 & $2.1(.7)$ & 14.08 & .68 & $4.84^{*}$ & 1 & .03 \\
\hline
\end{tabular}

Note. ${ }^{*} p \leq 0.01 * p \leq 0.05 ; M$ was analyzed on a four-point Likert scale $(0=$ not true, $1=$ partly not true, $2=$ partly true, $3=$ true).

The relative treatment effect (RTE) of the DVC increased $\left(\mathrm{DVC}_{\text {pre }}=0.37 ; \mathrm{DVC}_{\text {post }}=0.68\right)$, whereas the ATP's one decreased $\left(\mathrm{ATP}_{\text {pre }}=0.56\right.$; $\left.\mathrm{ATP}_{\text {post }}=0.38\right)$ significantly over time. From a parametrical perspective, instructional strategies for clarifying lesson goals (e.g. clear formulation of the central question in the beginning of the lesson) were observed in the DVC at a mean score of $M=1.50(S D=0.82)$ at the pre-test, which increased to a mean score of $M=2.06(S D=0.71)$ at post-test. In the ATP, instructional strategies for clarifying lesson goals were observed at a mean score of $M=1.44(S D=0.88)$ pre-test. This mean dropped to $M=1.25(S D=$ $0.80)$ post-test.

Furthermore, a Wilcoxon signed-rank test showed a significant positive change in the DVC teachers' practices ( $Z$ $=-2.21, p=0.03$ ) from pre to post-test. The median goal clarity rating was 1.16 for the pre-test and 1.71 for the post-test, whereas the learning environment of the ATP did not lead to a significant change in teaching practice $(Z=-0.74, p=0.46)$. Indeed, median goal clarity rating was 1.66 for pre-test and 1.13 for post-test.

\subsection{Teacher Discussions (Research Question 2)}

In order to illustrate these findings on teachers' practice, we analyzed DVC teachers' discussions. Table 4 illustrates to what extent teachers discussions were focused on the content of goal clarity in classroom dialogue (Research Question 2.1). In both cycles, between 23\% and 37\% of the two-minute units of analysis were coded as units in which discussions about goal clarity took place. Comparing the two cycles, there was a decrease in discussions about goal clarity from the first to the second cycle. In addition, goal clarity was more frequently addressed in the planning workshops in which discussions about adapting lesson plans took place. 
Table 4. Content focus in (video-based) teacher discussions during DVC workshops

\begin{tabular}{|c|c|c|c|c|c|c|c|c|}
\hline & \multicolumn{4}{|c|}{ DVC 1} & \multicolumn{4}{|c|}{ DVC 2} \\
\hline & \multicolumn{2}{|c|}{ Planning Workshop } & \multicolumn{2}{|c|}{ Reflection Workshop $1 \& 2$} & \multicolumn{2}{|c|}{ Planning Workshop } & \multicolumn{2}{|c|}{ Reflection Workshop $1 \& 2$} \\
\hline & $n[\%]$ & $n$ & $n[\%]$ & $n$ & $n[\%]$ & $n$ & $n[\%]$ & $n$ \\
\hline Goal clarity & 37 & 31 & 33 & 30 & 28 & 22 & 23 & 21 \\
\hline Segments in total & 100 & 83 & 100 & 92 & 100 & 79 & 100 & 90 \\
\hline
\end{tabular}

Note. $\mathrm{n}$ segments in total were the total amount of two-minute units of analysis coded in the particular workshop; $\mathrm{n}[\%]$ segments in total were the relative frequencies of two-minute units of analysis coded in the particular workshop.

Furthermore we examined teachers' active participation in the discussions (Research Question 2.2). Our findings show that the distribution of the verbal activity between the facilitator, the on-screen teacher and teachers in the learning community was almost constant over time (see Figure 2).

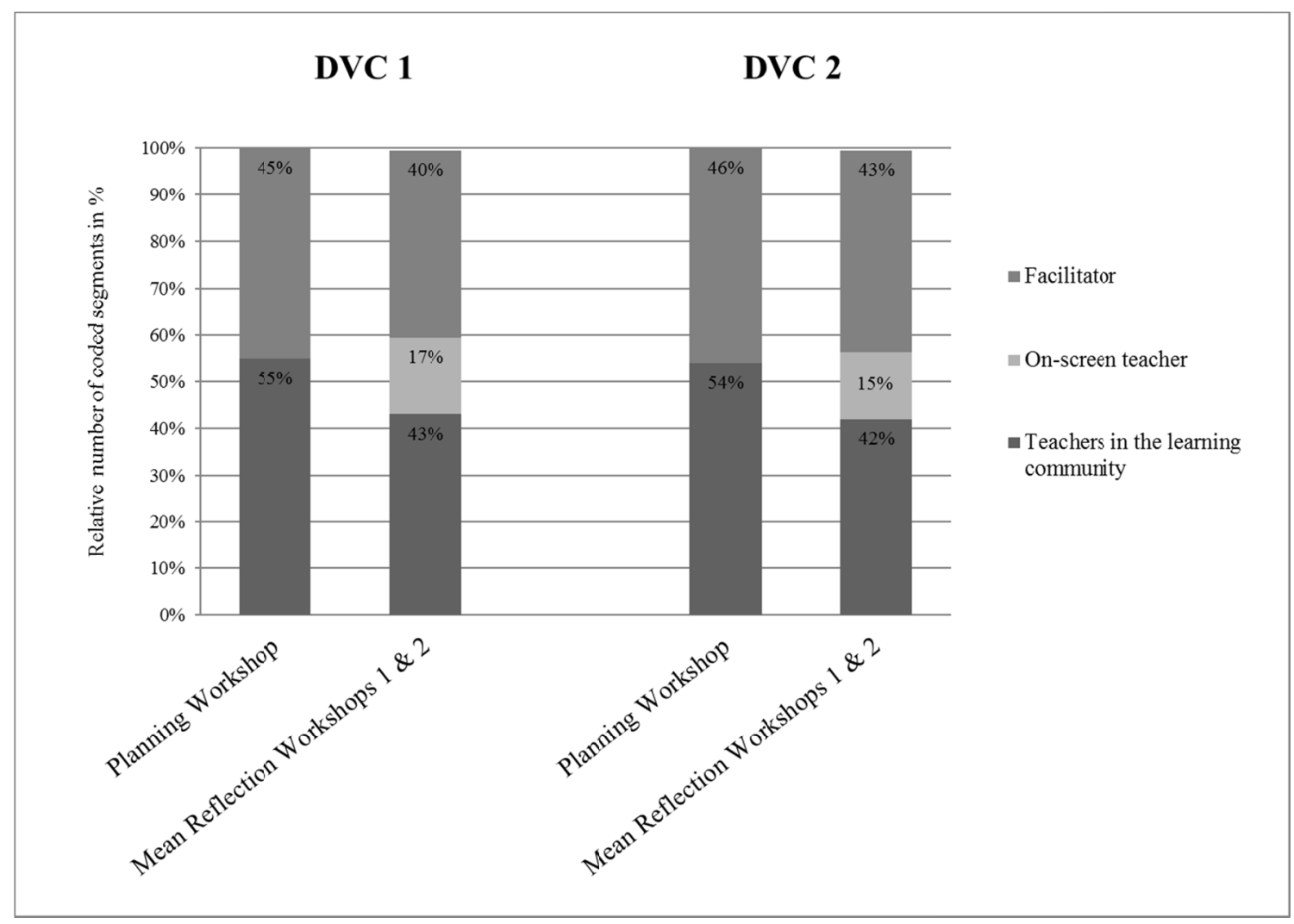

Figure 2. Active and social exchange during DVC (video-based) teacher discussions

Through both DV cycles, the teachers (in the learning community plus the on-screen teacher) had a high proportion of verbal activity in the discussions about goal clarity (between $45 \%$ and $58 \%$ of units of analysis). In the reflection workshops, the verbal activity of the teachers was distributed between teachers in the learning community and the on-screen teacher. Each teacher was part of the learning community during the entire DVC and served as the on-screen teacher at least once during each DVC. The facilitator's verbal activity was more frequently coded in the planning workshops (about $55 \%$ of units of analysis) than in the reflection workshops (about $43 \%$ of units of analysis).

In order to illustrate the nature of the DVC (video-based) teacher discussions, qualitative excerpts are presented in the following. The first excerpt exemplifies the discussion about Sarah's (teacher participating in the DVC) lesson plan in the planning workshop of the first DVC. Sarah was planning her next chemistry lesson about the topic "aldehyde" and was not sure whether she could improve her teaching strategies. 
Facilitator: What do you think about using a goal plan to visualize the lesson structure? I think this would be motivating for the students.

Sarah: Yes, you are right. I think this is a good idea. Do you think I should have incorporated a goal plan into my previous lesson, too?

Facilitator: No, I don't think so.

Sarah: I think, for this lesson, a goal plan would be beneficial because we will be working on the topic "aldehyde", which the students already know. The aim of the lesson is to do exercises. When you [looking at Laura and Caroline, two colleagues during this discussion] talked about a goal plan for your lessons, I was thinking about how I could integrate one into my lesson, too.

(Planning Workshop, DVC 1)

In the following, the facilitator moderated the discussion and supported the teachers in thinking about opportunities for Sarah to incorporate a goal plan. The teachers shared their experiences and related their discussion to Sarah's lesson so that she was able to incorporate some instructional strategies for a productive classroom dialogue. In the reflection workshop of DVC 1, the teachers watched the video excerpt in which Sarah clarified the lesson goals with a goal plan.

Thomas: I like the way you integrate the goal plan. That makes the lesson structure transparent for students. (...)

Sarah: I have never used a goal plan like this. Typically, I explain the first task and after finishing it, I explain the second and so on. (...)

Lucy: I think in this case the goal plan was perfect. The students already knew the terms you used. If they had never heard the term "aldehyde reaction equation" before, the goal plan could have been very scary.

Facilitator: But, do you remember Marc's (math) video? He said something like "In the end, you will be able to calculate the surface area of every polygon.", and this was very activating for the students.

Marc: Right, you do not have to use such complex terms. Just formulate the goals in simple terms!

Thomas: What is important is that the students know the goals. (...) This is like hiking. The students see one hill after another and they do not know how far away the mountain peak is.

\section{Discussion}

The Dialogic Video Cycle (DVC) is an example of a long-term practice-based TPD program on classroom dialogue. The aim of this study was to examine the extent to which the learning environment of the Dialogic Video Cycle supported teachers in changing their dialogic teaching practices compared to an Advanced Traditional Program (ATP). So far, common approaches have investigated the degree to which a TPD program has an impact on teacher learning by analyzing teachers' practices before and after the intervention. In the case where teachers changed their teaching practice after participating in the intervention, we can assume that the teachers benefited from engaging in the program. However, this kind of approach does not provide further information about effective instructional elements and the process of teacher learning during the intervention. Therefore, in order to learn more about important and effective TPD elements, such as content focus and active, social learning in a community of teachers (Desimone, 2009), we analyzed teacher discussions during TPD workshops in more detail.

As conjectured, the findings of this study show that teachers participating in the DVC changed their dialogic teaching practices and incorporated elements of goal clarity more explicitly compared to teachers in the ATP program (conjecture 1). The DVC's practice-based approach, thus, provided more opportunities for the teachers to learn and to practice (Lampert, 2009; Loewenberg Ball \& Forzani, 2009). Putting TPD into practice, for example, using teaching artifacts like lesson plans and video excerpts of their own teaching might have encouraged teachers' individual as well as community-based learning processes and might have provoked practice changes in teachers' classrooms (Ball \& Cohen, 1999; Jacobs et al., 2009). This is in line with previous research (Borko et al., 2008), which showed that teaching artifacts provide rich opportunities for teachers to actively exchange information about their own teaching and support one another in changing their practices. 
The systematic analysis of teacher discussions in the DVC illustrates that teachers' changes in practice went along with a considerable period of time discussing these aspects during the planning and reflection workshops (conjecture 2a). This is in line with Borko and colleagues' (2008) findings, which showed that video excerpts of one's own teaching supported productive discussions. Video excerpts helped teachers to focus on relevant issues and to change their perspective on student learning. Contrary to our assumptions, there was a decrease in teacher discussions on goal clarity between the first and the second DVC. The TPD program focused on goal clarity as an essential instructional strategy for the verbal engagement of students. However, beyond that, teachers addressed a number of further effective instructional strategies during classroom dialogue in the intervention. The decrease in discussions about goal clarity can be interpreted as an artifact that teachers shifted their attention in the second DVC to other methods and strategies (Michaels et al., 2008) such as teacher feedback.

In line with our conjecture $2 b$, our analyses indicate that collective participation and active learning among the teachers and facilitator, which were both fully observed in the DVC and targeted in the ATP at a lower level, are essential elements for teachers' learning (Desimone, 2009; Wilson, 2013). A learning community provides a space for teachers to actively learn and collaborate and discuss their teaching methods with regard to a shared goal (van Es, 2012). Encouraged through the practice-based video excerpts, DVC teachers continuously discussed their own practices and collectively linked visual experiences during discussions to their teaching routine. The qualitative excerpts from the workshops illustrate how teachers in the learning community, the on-screen teacher and the facilitator exchanged information about methods and strategies for improving goal clarity in their instruction. In the planning workshop, Sarah (teacher in the DVC) was explicitly supported by the facilitator in incorporating a concrete instructional strategy for clarifying the lesson goal. Therefore, the facilitator asked her directly what she was thinking about a goal plan in order to visualize the lesson structure and ensure that she focused on the content. Unlike in the reflection workshop, the teachers discussed their ideas about Sarah's video excerpt without input from the facilitator. They related the discussion to the pedagogical TPD content, addressed their own teaching routines and shared their experiences. The facilitator just intervened to guide teachers' attention to a previous video. As the example shows, the role of the facilitator changed. While the teachers might need to be pushed by a facilitator toward trying out new instructional practices in a planning workshop, the teachers, as a learning community, took up this initiation within the group and jointly reflected on this issue without further input from a facilitator. In the reflection workshop, the facilitator was then in the role of expanding teachers' ideas or connecting different thoughts in order to foster active involvement and social learning (Borko et al., 2008; van Es, Tunney, Goldsmith, \& Seago, 2014).

\section{Conclusion}

In summary, our study illustrates how components of effective TPD, such as content focus and social, active learning, translate into redefinitions and changes in classroom dialogue. Goal clarity in instruction can improve the classroom dialogue by explicating learning goals to students and verbally structuring the course of the lessons.

In addition, our study provides further support for practice-based TPD approaches that use artifacts like lesson plans and video excerpts of one's own teaching to foster teachers' active learning of content and to promote teachers' transfer of TPD contents to the teaching practice. Beyond the focus on practice-based elements in teacher education, future research should pay close attention to putting TPD into practice.

Furthermore, our findings suggest that the facilitator takes a leading role in framing the discussions purposefully in order to support teachers' social and active exchanges.

The study added to the current state of TPD research by relating changes in teachers' practices to components of effective TPD. Within this context, the study's limitation was the small sample size of participating teachers and thus the findings are not generalizable to broad cohorts of teachers. For future research, however, the knowledge from this small-scale study could be expanded to a larger teacher sample (Wayne, Yoon, Zhu, Cronen, \& Garet, 2008). Moreover, the findings on full-group teacher discussions are based on a frequency analysis of the verbal activity of the facilitator, the on-screen teacher and teachers in the learning community; no conclusion can be drawn about the type of conversation that took place among the teachers. This will be part of a follow-up study taking into account the findings of Borko and colleagues (2008) that the discussions surrounding the video became more productive because teachers talked in a more analytical manner about specific issues in their PD. We are not able to show individual differences between teachers participating in the DVC in more depth. For that reason, further analyses will address teachers' individual practice changes as well as individual verbal activity during the (video-based) discussions to understand how individual teachers learn during TPD (Kazemi \& Hubbard, 2008). Furthermore, additional analyses will consider the type of (video-based) discussions to acquire 
in-depth information about the degree of productivity. Our findings indicate that the potential of practice-based TPD in comparison to traditional TPD may be useful for video and facilitation-based programs and studies in the future.

\section{Acknowledgments}

This research was supported by a grant from the German Research Foundation (DFG, grant number SE 1397/5-1). We would like to thank the teachers who participated in the project. We thank Ann-Kathrin Schindler, Katharina Kiemer and Christina Knöss for their engagement in data collection and analysis.

\section{References}

Alexander, R. (2008). Towards dialogic teaching: Rethinking classroom talk. UK Ltd: Doalogos.

Arya, P., Christ, T., \& Chiu, M. (2014). Facilitation and teacher behaviors: An analysis of literacy teachers' video-case discussions. Journal of Teacher Education, 65(2), 111-127. https://doi.org/10.1177/0022487113511644

Ball, D. L., \& Cohen, D. K. Developing practice, developing practitioners: Torwards a practice-based theory of professional education. In G. Sykes \& L. Darling-Hammond (Eds.), Teaching as the learning profession: Handbook of policy and practice (pp. 3-32). San Francisco, CA: Jossey-Bass Publishers. Retrieved from $\mathrm{http} / / / \mathrm{www}-$ personal.umich.edu/ dkcohen/downloads/developingpractice.pdf

Ball, D. L., \& Cohen, D. K. (1999). Developing practice, developing practitioners: Toward a practice-based theory of professional education. In L. Darling-Hammond, \& G. Sykes (Eds.), The Jossey-Bass education series. Teaching as the learning profession. Handbook of policy and practice (pp. 3-32). San Francisco, CA: Jossey-Bass Publishers.

Borich, G. D. (2014). Effective teaching methods: Research-based practice (8th ed.). Boston, MA: Pearson Education.

Borko, H. (2004). Professional development and teacher learning: Mapping the terrain. Educational Researcher, 33(8), 3-15. https://doi.org/10.3102/0013189x033008003

Borko, H., Jacobs, J., Eiteljorg, E., \& Pittman, M. E. (2008). Video as a tool for fostering productive discussions in mathematics professional development. Teaching and Teacher Education, 24(2), 417-436. https://doi.org/10.1016/j.tate.2006.11.012

Coles, A. (2013). Using video for professional development: The role of the discussion facilitator. Journal of Mathematics Teacher Education, 16(3), 165-184. https://doi.org/10.1007/s10857-012-9225-0

Desimone, L. M. (2009). Improving impact studies of teachers' professional development: Toward better conceptualizations and measures. Educational Researcher, 38(3), 181-199. https://doi.org/10.3102/0013189x08331140

Dobie, T. E., \& Anderson, E. R. (2015). Interaction in teacher communities: Three forms teachers use to express contrasting ideas in video clubs. Teaching and Teacher Education, 47, 230-240. https://doi.org/10.1016/j.tate.2015.01.003

DuFour, R., \& Eaker, R. E. (1998). Professional learning communities at work: Best practices for enhancing student achievement. Bloomington, Ind., Alexandria, Va.: National Education Service; ASCD.

Gaudin, C., \& Chaliès, S. (2015). Video viewing in teacher education and professional development: A literature review. Educational Research Review, 16, 41-67. https://doi.org/10.1016/j.edurev.2015.06.001

Gröschner, A., Seidel, T., Pehmer, A.-K., \& Kiemer, K. (2014). Facilitating collaborative teacher learning: The role of "mindfulness" in video-based teacher professional development programs. Gruppendynamik \& Organisationsberatung, 45(3), 273-290. https://doi.org/10.1007/s11612-014-0248-0

Gröschner, A., Seidel, T., Kiemer, K., \& Pehmer, A.-K. (2015). Through the lens of teacher professional development components: The 'Dialogic Video Cycle' as an innovative program to foster classroom $\begin{array}{llll}\text { dialogue. Professional Development in Education, 41(4), } & \text { 729-756. }\end{array}$ https://doi.org/10.1080/19415257.2014.939692

Grossman, P., Compton, C., Igra, D., Ronfeldt, M., \& Shahan, Emily, Williamson, Peter W. (2009). Teaching practice: A cross-professional perspective. Teacher College Record, 11(9), 2055-2100.

Hattie, J. (2009). Visible learning: A synthesis of over 800 meta-analyses relating to achievement. London, England: Routledge. 
Hiebert, J., Gallimore, R., Garnier, H., Bogard-Givvin, K., Hollingsworth, H., Jacobs, J., . . Stigler, J. (2003). Teaching mathematics in seven countries: Results from the TIMSS 1999 video study. Washington, DC: U.S. Department of Education.

Howe, C., \& Abedin, M. (2013). Classroom dialogue: A systematic review across four decades of research. Cambridge Journal of Education, 43(3), 325-356. https://doi.org/10.1080/0305764x.2013.786024

Hugener, I., Pauli, C., Reusser, K., Lipowsky, F., Rakoczy, K., \& Klieme, E. (2009). Teaching patterns and learning quality in Swiss and German mathematics lessons. Learning and Instruction, 19(1), 66-78. https://doi.org/10.1016/j.learninstruc.2008.02.001

Jacobs, J., Borko, H., \& Koellner, K. (2009). The power of video as a tool for professional development and research: Examples from the Problem-Solving Cycle. In T. Janík \& T. Seidel (Eds.), The power of video studies in investigating teaching and learning in the classroom (pp. 259-273). Muenster, Germany: Waxman.

Kazemi, E., \& Hubbard, A. (2008). New directions for the design and study of professional development: Attending to the coevolution of teachers' participation across contexts. Journal of Teacher Education, 59(5), 428-441. https://doi.org/10.1177/0022487108324330

Kleinknecht, M., \& Schneider, J. (2013). What do teachers think and feel when analyzing videos of themselves and other teachers teaching? Teaching and Teacher Education, 33, 13-23. https://doi.org/10.1016/j.tate.2013.02.002

Kovalainen, M., \& Kumpulainen, K. (2005). The discursive practice of participation in an elementary classroom community. Instructional Science, 33(3), 213-250. https://doi.org/10.1007/s11251-005-2810-1

Krammer, K., Ratzka, N., Klieme, E., Lipowsky, F., Pauli, C., \& Reusser, K. (2006). Learning with classroom videos: Conception and first results of an online teacher-training program. Zentralblatt für Didaktik der Mathematik, 38(5), 422-432. https://doi.org/10.1007/BF02652803

Lampert, M. (2009). Learning teaching in, from, and for practice: What do we mean? Journal of Teacher Education, 61(1-2), 21-34. https://doi.org/10.1177/0022487109347321

Lauer, P. A., Christopher, D. E., Firpo-Triplett, R., \& Buchting, F. (2014). The impact of short-term professional development on participant outcomes: A review of the literature. Professional Development in Education, 40(2), 207-227. https://doi.org/10.1080/19415257.2013.776619

Loewenberg Ball, D., \& Forzani, F. M. (2009). The work of teaching and the challenge for teacher education. Journal of Teacher Education, 60(5), 497-511. https://doi.org/10.1177/0022487109348479

Marsh, B., \& Mitchell, N. (2014). The role of video in teacher professional development. Teacher Development, 18(3), 403-417. https://doi.org/10.1080/13664530.2014.938106

Mehan, H. (1979). Learning lessons: Social organization in the classroom. Cambridge, England: Harvard University Press.

Mercer, N., \& Dawes, L. (2014). The study of talk between teachers and students, from the 1970s until the 2010s. Oxford Review of Education, 40(4), 430-445. https://doi.org/10.1080/03054985.2014.934087

Michaels, S., O'Connor, C., \& Resnick, L. B. (2008). Deliberative discourse idealized and realized: Accountable talk in the classroom and in civic life. Studies in Philosophy and Education, 27(4), 283-297. https://doi.org/10.1007/s11217-007-9071-1

Molle, D. (2013). Facilitating professional development for teachers of English language learners. Teaching and Teacher Education, 29, 197-207. https://doi.org/10.1016/j.tate.2012.10.002

Moreno, R., \& Valdez, A. (2007). Immediate and delayed effects of using a classroom case exemplar in teacher education: The role of presentation format. Journal of Educational Psychology, 99(1), 194-206. https://doi.org/10.1037/0022-0663.99.1.194

Osborne, J., Simon, S., Christodoulou, A., Howell-Richardson, C., \& Richardson, K. (2013). Learning to argue: A study of four Schools and their attempt to develop the use of argumentation as as a common instructional practice and its impact on students. Journal of Research in Science Teaching, 50(3), 315-347. https://doi.org/10.1002/tea.21073

Pehmer, A.-K., Gröschner, A., \& Seidel, T. (2015). Fostering and scaffolding student engagement in productive classroom discourse: Teachers' practice changes and reflections in light of teacher professional development. 
Learning, Culture and Social Interaction, 7, 12-27. https://doi.org/10.1016/j.lcsi.2015.05.001

Rakoczy, K., Klieme, E., Drollinger-Vetter, B., Lipowsky, L., Pauli, C., \& Reusser, K. (2007). Structure as a quality feature in mathematics instruction: Cognitive and motivational effects of a structued organization of the learning environment vs. a structured presentation of learning content. In M. Prenzel (Ed.), BIQUA. Studies on the educational quality of schools. The final report on the DFG priority programme (pp. 102-121). Muenster, Germany: Waxmann.

Resnick, L. B., Asterhan, C. S., \& Clarke, S. N. (Eds.). (2015). Socializing intelligence through academic talk and dialogue. Washington, DC: American Educational Research Association.

Reznitskaya, A., \& Wilkinson, I. A. G. (2015). Positively transforming classroom practice through dialogic teaching. In S. Joseph (Ed.), Positive psychology in practice (pp. 279-296). Hoboken, NJ: John Wiley \& Sons Inc. https://doi.org/10.1002/9781118996874.ch17

Richter, D., Kunter, M., Klusmann, U., Lüdtke, O., \& Baumert, J. (2011). Professional development across the teaching career: Teachers' uptake of formal and informal learning opportunities. Teaching and Teacher Education, 27(1), 116-126. https://doi.org/10.1016/j.tate.2010.07.008

Rimmele, R. (2002). Videograph. Kiel: IPN.

Scheerens, J. (2010). Teachers' professional development: Europe in international comparison; an analysis of teachers' professional development based on the OECD's Teaching and Learning International Survey (TALIS). Luxembourg, LUX: Office for Official Publ. of the European Union; European Commission.

Sedova, K., Sedlacek, M., \& Svaricek, R. (2016). Teacher professional development as a means of transforming student classroom talk. Teaching and Teacher Education, 57, 14-25. https://doi.org/10.1016/j.tate.2016.03.005

Seidel, T., \& Prenzel, M. (2006). Stability of teaching patterns in physics instruction: Findings from a video study. Learning and Instruction, 16(3), 228-240. https://doi.org/10.1016/j.learninstruc.2006.03.002

Seidel, T., Prenzel, M., \& Kobarg, M. (Eds.). (2005). How to run a video study: Technical report of the IPN video study. Muenster, Germany: Waxmann.

Seidel, T., Rimmele, R., \& Prenzel, M. (2005). Clarity and coherence of lesson goals as a scaffold for student learning. Learning and Instruction, 15(6), 539-556. https://doi.org/10.1016/j.learninstruc.2005.08.004

Seidel, T., Stürmer, K., Blomberg, G., Kobarg, M., \& Schwindt, K. (2011). Teacher learning from analysis of videotaped classroom situations: Does it make a difference whether teachers observe their own teaching or that of others? Teaching and Teacher Education, 27(2), 259-267. https://doi.org/10.1016/j.tate.2010.08.009

Stoll, L., Bolam, R., McMahon, A., Wallace, M., \& Thomas, S. (2006). Professional learning communities: A review of the literature. Journal of Educational Change, 7(4), 221-258. https://doi.org/10.1007/s10833-006-0001-8

Stowell, S. (2014). Using R for statistics. Berkeley, CA: Apress.

Timperley, H., Wilson, A., Barrar, H., \& Fung, I. (2007). Teacher professional learning and development. Best Evidence Synthesis Iteration [BES]. Wellington, New Zealand: Ministry of Education.

van Es, E., Tunney, J., Seago, N., \& Goldsmith, L. T. (2015). Facilitation practices for supporting teacher learning with video. In P. J. Rich \& B. Calandra (Eds.), Digital video for teacher education. Research and practice (pp. 109-127). New York, NY: Routledge.

van Es, E. A. (2011). A framework for learning to notice student thinking. In M. G. Sherin, V. R. Jacobs, \& R. A. Philipp (Eds.), Mathematics teacher noticing. Seeing through teachers' eyes (pp. 134-151). New York, NY: Routledge.

van Es, E. A., Tunney, J., Goldsmith, L. T., \& Seago, N. (2014). A framework for the facilitation of teachers' analysis of video. Journal of Teacher Education, 65(4), 340-356. https://doi.org/10.1177/0022487114534266

van Es, E. A. (2012). Examining the development of a teacher learning community: The case of a video club. Teaching and Teacher Education, 28(2), 182-192. https://doi.org/10.1016/j.tate.2011.09.005

Vangrieken, K., Meredith, C., Packer, T., \& Kyndt, E. (2017). Teacher communities as a context for professional development: A systematic review. Teaching and Teacher Education, 61, 47-59. https://doi.org/10.1016/j.tate.2016.10.001 
Vigerske, S. (2017). Transfer von Lehrerfortbildungsinhalten in die Praxis. Wiesbaden: Springer Fachmedien Wiesbaden.

Walshaw, M., \& Anthony, G. (2008). The teacher's role in classroom discourse: A review of recent research into mathematics classrooms. Review of Educational Research, 78(3), 516-551. https://doi.org/10.3102/0034654308320292

Wayne, A. J., Yoon, K. S., Zhu, P., Cronen, S., \& Garet, M. S. (2008). Experimenting with teacher professional development: Motives and methods. Educational Researcher, 37(8), 469-479. https://doi.org/10.3102/0013189X08327154

Wilson, S. M. (2013). Professional development for science teachers. Science, 340(6130), 310-313. https://doi.org/10.1126/science. 1230725

Zhang, M., Koheler, M., \& Lundeberg, M. (2015). Affordances and challenges of different types of video for teachers' professional development. In P. J. Rich, \& B. Calandra (Eds.), Digital video for teacher education. Research and practice. New York, NY: Routledge.

\section{Copyrights}

Copyright for this article is retained by the author(s), with first publication rights granted to the journal.

This is an open-access article distributed under the terms and conditions of the Creative Commons Attribution license (http://creativecommons.org/licenses/by/4.0/). 